Volume 11, Nomor 1, Mei 2019, pp 176 - 186 Copyright (C) 2017 Jurnal Akuntansi Maranatha, Program Studi Akuntansi, Fakultas Ekonomi,Universitas Kristen Maranatha. ISSN 2085-8698 | e-ISSN 2598-4977. http://journal.maranatha.edu

\title{
Pengaruh Kualitas Pelayanan Account Representative (AR) dan Tax Knowledge terhadap Kepatuhan Wajib Pajak (Studi pada Wilayah KPP Madya Bandung)"
}

\author{
Yuliana Gunawan \\ Fakultas Ekonomi Program Studi Akuntansi-Univ.Kristen Maranatha \\ (Jl. Prof. Drg. Suria Sumantri No. 65, Bandung) \\ yuliana_ok99@yahoo.com \\ Meyliana \\ Fakultas Ekonomi Program Studi Akuntansi-Univ.Kristen Maranatha \\ (Jl. Prof. Drg. Suria Sumantri No. 65, Bandung) \\ meyliana_oey@yahoo.com \\ Maria Natalia \\ Fakultas Ekonomi Program Studi Akuntansi-Univ.Kristen Maranatha \\ (Jl. Prof. Drg. Suria Sumantri No. 65, Bandung) \\ maria_natalia_2312@yahoo.com
}

\begin{abstract}
Abstrak
Penelitian ini bertujuan untuk menguji dan menemukan bukti empiris apakah Kualitas Pelayanan Account Representative (AR) dan Tax Knowledge berpengaruh terhadap Kepatuhan Wajib Pajak (Studi pada Wilayah KPP Madya Bandung). Sampel yang digunakan dalam penelitian ini adalah Wajib Pajak aktif yang terdaftar di KPP Madya Bandung.Data dikumpulkan menggunakan metode incidental sampling.Pengumpulan data dilakukan dengan penyebaran kuesioner.Jumlah kuesioner yang terkumpul sebanyak 78 kuesioner dari 120 kuesioner yang disebar.Penelitian ini dianalisis dengan menggunakan model analisis regresi berganda. Hasil penelitian ini menunjukkan bahwa terdapat pengaruh yang signifikan Kualitas Pelayanan Account Representative terhadap Kepatuhan Wajib Pajak namun tidak terdapat pengaruh Tax Knowledge terhadap Kepatuhan Wajib Pajak.
\end{abstract}

Kata Kunci:Kualitas Pelayanan Account Representative (AR), Tax Knowledge, Kepatuhan Wajib Pajak

\section{Pendahuluan}

Pajak merupakan penopang terbesar dari Anggaran Pendapatan dan Belanja Negara (APBN).Untuk

memaksimalkan penerimaan pajak sebagai sumber penerimaan negara, perlu dilakukan reformasi perpajakan yang dilakukan dari masa ke masa dengan tetap berasaskan pada keadilan sosial.Reformasi perpajakan tersebut dilakukan untuk dapat memperluas dan menambah wajib pajak serta meningkatkan kesadaran dan kepatuhan 
wajib pajak dalam membayar pajak.Untuk dapat memperluas basis pajak tersebut, perlu juga dilakukan pelayanan prima terhadap setiap wajib pajak baik yang sudah terdaftar maupun belum terdaftar sebagai wajib pajak.Salah satu dari perubahan reformasi birokrasi dalam perpajakan yang merupakan perwujudan dari modernisasi perpajakan atau yang lebih dikenal dengan istilah Sistem Administrasi Perpajakan Modern adalah dibentuknya Account Representative (http://ekstensifikasi423.blogspot.com/2015 /05/account-representative-ar-dulu-dankini.html). Menurut Keputusan Menteri Keuangan nomor 98/KMK.01/2006 tentang Account Representative menyatakan tugas AR antara lain: 1) melakukan pengawasan kepatuhan wajib pajak; 2)bimbingan/himbauan dan konsultasi teknis perpajakan kepada wajib pajak, 3) penyusunan profil wajib pajak, 4) analisis kinerja wajib pajak, rekonsiliasi data wajib pajak dalam rangka intensifikasi; dan 5) melakukan evaluasi hasil banding berdasarkan ketentuan yang berlaku Wajib pajak sebagai pihak yang dibutuhkan oleh aparat pajak seharusnya memperoleh pelayanan dan pengawasan yang baik. Pelayanan dan pengawasan yang baik berpotensi untuk meningkatkan kepatuhan pajak.Kenyataan yang ada di Indonesia menunjukkan bahwa tingkat kepatuhan WP tergolong masih rendah.Fenomena kepatuhan WP yang masih rendah dapat dilihat dari belum optimalnya penerimaan pajak yang tercermin dari rasio pajak (perbandingan jumlah tidak selamanya WP yang tidak patuh adalah WP yang sengaja melanggar peraturan perundangundangan).Gubernur Provinsi Jawa Barat Ahmad Heryawan menyatakan tingkat kepatuhan masyarakat di Jawa Barat dalam membayar pajak masih rendah.Tidak hanya dalam pembayaran tapi juga pengembalian Surat Pemberitahuan Tahunan (SPT). Terbukti menurut Kepala Kantor Wilayah Pajak Jabar I Adjat Jatmika, dari sekitar 1,3 juta wajib pajak di Jabar pada 2011, hanya
$40 \%$ masuk kategori pembayar aktif. Sekitar 26\% wajib pajak dari badan (perusahaan) dan $14 \%$ wajib pajak perorangan. (Ahmad Heryawan 2012)Salah satu faktor yang menyebabkan WP tidak patuh menurut Marti et al (2010) dalam penelitiannya di Kenya adalah kurangnya kemampuan WP untuk memahami hukum pajak. Abuyamin (2010) menyatakan bahwa salah satu faktor penyebab WP secara pasif tidak membayar pajak (tidak patuh) adalah kurangnya pemahaman terhadap hukum pajak. Terutama sejak pemberlakuan sistem self assessment, WP dituntut untuk aktif secara mandiri dengan meng-up date dan memahami peraturan perpajakan sehingga mereka dapat memenuhi perpajakannya sesuai peraturan perundangundangan yang berlaku. Oleh sebab itu, Palil (2005) menyebutkan bahwa pengetahuan pajak merupakan persyaratan mendasar dalam keberhasilan penerapan sistem self assessment.Menurut Siti Kurnia Rahayu (2010) Kepatuhan wajib pajak dipengaruhi oleh beberapa faktor yaitu kondisi sistem administrasi perpajakan suatu Negara, pelayanan pada wajib pajak, penegakan hukum perpajakan, pemeriksaan pajak, dan tarif pajak.

Berdasarkan uraian di atas, penulis tertarik untuk melakukan penelitian lebih lanjut mengenai pengaruh antara persepsi WP terhadap kualitas pelayanan AR dan pengetahuan pajak (tax knowledge) dengan perilaku kepatuhan WP Badan di Wilayah KPP Madya Bandung. Oleh karena itu, dalam penelitian ini penulis menetapkan judul:

"Pengaruh Kualitas Pelayanan Account Representative (AR) dan Tax knowledge terhadap Kepatuhan Wajib Pajak (Studi pada Wilayah KPP Madya Bandung)"

Berdasarkan latar belakang penelitian, maka masalah dalam penelitian ini dapat diidentifikasi dan dirumuskan sebagai berikut: 
1. Apakah terdapat pengaruh yang signifikan kualitas pelayanan AR terhadap tingkat kepatuhan WP di Wilayah KPP Madya Bandung?

2. Apakah terdapat pengaruh signifikan tax knowledge terhadap tingkat kepatuhan WP di Wilayah KPP Madya Bandung?

\section{Kerangka Teoritis dan Hipotesis}

\section{Kualitas \\ Pelayanan \\ Representative (AR)}

Pengertian account representative menurut Liberti Pandiangan (2008:27) menyatakan bahwa:

"Pegawai Direktorat Jenderal Pajak (DJP) melaksanakan tugas-tugas pengawasan terhadap pelaksanaan kewajiban oleh wajib pajak dan melayani penyelesaian hak wajib pajak".

Menurut pengertian account representative di lingkungan Direktorat Jendral Pajak (DJP) dalam Jhon Hutagaol (2007:22) adalah:

"Pegawai Direktorat Jenderal Pajak (DJP) yang diberi kepercayaan, wewenang, dan tanggung jawab untuk memberikan pelayanan, pembinaan, dan pengawasan secara langsung kepada wajib pajak.

Pengertian account representative menurut Liberti Pandiangan (2008:27) menyatakan bahwa:

"Pegawai Direktorat Jenderal Pajak (DJP) melaksanakan tugas-tugas pengawasan terhadap pelaksanaan kewajiban oleh wajib pajak dan melayani penyelesaian hak wajib pajak".

Menurut pengertianaccount representative di lingkungan Direktorat Jendral Pajak (DJP) dalam Jhon Hutagaol (2007:22) adalah:

"Pegawai Direktorat Jenderal Pajak (DJP) yang diberi kepercayaan, wewenang, dan tanggung jawab untuk memberikan pelayanan, pembinaan, dan pengawasan secara langsung kepada wajib pajak
Menurut Peraturan Menteri Keuangan Nomor 79/PMK.01/2015 Tahun 2015 tentang Account Representative Pada Kantor Pelayanan Pajak ("Permenkeu 79/2015").

Pengertian Account Representative (AR) adalah pegawai yang diangkat dan ditetapkan sebagai Account Representative pada Kantor Pelayanan Pajak.

Account Representative merupakan salah satu ujung tombak penggalian potensi penerimaan Negara di bidang perpajakan yang mengemban tugas intensifikasi perpajakan melalui pemberian bimbingan/himbauan, konsultasi, analisis dan pengawasan terhadap Wajib Pajak Account Representative terdiri dari:
a. Account
Representative yang menjalankan fungsi pelayanan dan konsultasi Wajib Pajak; dan
b. Account Representative yang menjalankan fungsi pengawasan dan penggalian potensi Wajib Pajak

Account Representative (AR) berkewajiban melaksanakan pengawasan kepatuhan kewajiban perpajakan, melaksanakan bimbingan dan melaksanakan himbauan kepada WP.Setiap Account Representative (AR) mempunyai beberapa WP yang harus diawasi.Account Representative (AR) juga dilatih agar menjadi staf yang proaktif, bersikap melayani, dan memiliki pengetahuan perpajakan yang baik. Seorang Account Representative (AR) memiliki akses terhadap rekening WP secara online. Selain itu, WP dapat secara mudah menghubungi AR baik secara langsung datang ke KPP maupun menggunakan telepon atau e-mail. (Sunardi 2012)

Kinerja Account Representative (AR) pajak dapat dikaitkan dengan tugas nya yang telah ditetapkan Keputusan Menteri Keuangan Republik Indonesia Nomor 98/KMK.01/2006:

1. Melakukan pengawasan kepatuhan Perpajakan wajib pajak. 
2. Bimbingan/himbauan dan konsultasi teknis perpajakan kepada wajib pajak.

3. Penyusunan profil wajib pajak.

4. Analisis kinerja wajib pajak, rekonsiliasi data wajib pajak dalam rangka intensifikasi.

5. Melakukan evaluasi hasil banding berdasarkan ketentuan yang berlaku.

Salah satu tujuan pokok modernisasi administrasi perpajakan adalah peningkatan kualitas pelayanan kepada WP dan seluruh stakeholder perpajakan. Pelayanan adalah sentra dan indikator utama untuk membangun citra DJP, sehingga kualitas pelayanan harus terus menerus ditingkatkan dalam rangka mewujudkan harapan dan membangun kepercayaan WP dan stakeholder perpajakan terhadap DJP (Nasution 2006).

Kualitas pada dasarnya terkait dengan pelayanan yang terbaik, yaitu sikap atau cara dalam melayani WP secara memuaskan. Kualitas sering diartikan sebagai totalitas dari karakteristik suatu produk yang menunjang kemampuannya untuk memuaskan kebutuhan yang dispesifikasikan atau ditetapkan.(Tjiptono 2005).Menurut Wyckof dalam Suratno dan Purnama (2004), kualitas pelayanan adalah tingkat keunggulan yang diharapkan dari pengendalian atas tingkat keunggulan tersebut untuk memenuhi keinginan pelanggan.

Lehtien dan Lehtien dalam Tjiptono (2005) mengemukakan dua ukuran kualitas pelayanan, yaitu process quality (yang dievaluasi pelanggan selama pelayanan diberikan) dan output quality (yang dievaluasi setelah pelayanan diberikan). Sementara itu Gronroos dalam Tjiptono (2005) memaparkan tiga ukuran kualitas pelayanan lainnya yang hampir sama yaitu technical quality (berkaitan dengan apa yang diterima pelanggan), functional quality (berkaitan dengan cara pelayanan diberikan), dan corporate quality (berhubungan dengan citra perusahaan).

\section{Tax Knowledge}

Nowak dalam Hidayat (2011) menyatakan bahwa peningkatan penerimaan pajak akibat verifikasi aparat perpajakan, aktivitas para ahli hukum, para akuntan dan teknisi lainnya, serta keputusan peradilan pajak, biasanya hanya merupakan $3 \%-5 \%$ dari seluruh penerimaan pajak, sedang sisanya sebesar 95\% adalah hasil dari pengembangan iklim perpajakan. Adapun ilkim perpajakan tersebut bercirikan hal-hal di bawah ini:

1. WP paham atau berusaha untuk memahami ketentuan peraturan perundangundangan perpajakan.

2. Mengisi formulir pajak dengan tepat.

3. Menghitung pajak dengan jumlah yang benar.

4. Membayar pajak tepat pada waktunya.

Dengan demikian iklim perpajakan yang kondusif adalah ketika WP memiliki pengetahuan tentang peraturan perundangundangan sehingga dapat menghitung pajak dengan benar.

Pengertian tax knowledge sendiri sebagaimana dikemukakan oleh para ahli, adalah sebagai berikut:

1. Viswanathan dalam Roshidi et al (2007) menyatakan bahwa knowledge as one of the factors in compliance is related to the tapayers' ability to understand taxation laws, and their willingness to comply.

2. Tan dan Chin-Fatt; Eriksen dan Fallan dalam Roshidi et al (2007) menyebutkan bahwa the aspect of knowledge that relates to compliance is the general understanding about taxation regulations and information pertaining to the opportunity to evade tax.

3. Loo et al (2009) menyatakan bahwa tax knowledge refers to a taxpayer's ability to correctly 
report his or her taxable income, claim relief and rebates, and compute tax liability.

Selain itu, pengetahuan perpajakan diperlukan untuk meningkatkan kesadaran politik dalam hal-hal yang menekankan hukum perpajakan, peran pajak dalam pembangunan nasional, dan khususnya dalam hal bagaimana dan kemana uang pajak yang dikumpulkan itu digunakan oleh pemerintah (Mohani dalam Roshidi et al, 2007). Pemahaman perpajakan akan menghasilkan prilaku positif WP sehingga mereka akan mengurangi tindakan dalam menghindari pajak. Palil (2005) mengemukakan bahwa tax knowledge merupakan persyaratan dasar dalam penerapan sistem selft assessment.

Dalam penelitian Widayati dan Nurlis (2010) untuk mengetahui pengetahuan dan pemahaman wajib pajak terhadap peraturan perpajakan, dapat dilihat dari beberapa hal, yaitu pertama, kepemilikan NPWP. Pasal 1 ayat 6 Undang-Undang Nomor 28 tahun 2007 Tentang"Ketentuan Umum dan Tata Cara Perpajakan", menyatakan bahwa Nomor Pokok Wajib Pajak (NPWP) adalah nomor yang diberikan kepada wajib pajak sebagai sarana dalam administrasi perpajakan yang dipergunakan sebagai tanda pengenal diri atau identitas wajib pajak dalam melaksanakan hak dan kewajiban perpajakannya. Kedua, pengetahuan dan pemahaman mengenai hak dan kewajiban sebagai wajib pajak. Apabila wajib pajak telah mengetahui dan memahami hak wajib pajak seperti penggunaan fasilitas umum, pemakaian jalan raya yang halus, pembangunan sekolah-sekolah negeri dan lain-lain, dan mengetahui kewajibannya sebagai wajib pajak seperti membayar pajak dan melaporkan Surat Pemberitahuan (SPT) tepat waktu, maka mereka akan melakukan kewajiban perpajakannya. Ketiga, pengetahuan dan pemahaman mengenai sanksi perpajakan, semakin tahu dan paham wajib pajak terhadap peraturan perpajakan, maka semakin tahu dan paham pula wajib pajak terhadap sanksi yang akan diterima bila melalaikan kewajiban perpajakan mereka. Hal ini tentu akan mendorong setiap wajib pajak yang taat akan menjalankan kewajibannya dengan baik. Keempat, pengetahuan dan pemahaman mengenai Penghasilan Tidak Kena Pajak (PTKP). Dengan mengetahui dan memahami mengenai tarif pajak yang berlaku, maka akan dapat mendorong wajib pajak untuk dapat menghitung kewajiban pajak sendiri secara benar. Kelima, adalah wajib pajak mengetahui sosialisasi yang dilakukan oleh Kantor Pelayanan Pajak dan yang keenam adalah bahwa wajib pajak mengetahui dan memahami peraturan pajak melalui training perpajakan yang mereka ikuti.

Pengaruh Kualitas Pelayanan Account Representative (AR) dan Tax Knowledge terhadap Kepatuhan Wajib Pajak

Adapun peneliti terdahulu yang membahas mengenai Kualitas pelayanan AccountRepresentative (AR) dan Tax Knowledge terhadap Kepatuhan Wajib Pajak antara lain:

- Febri Alfiansyah (2012), meneliti tentang: Pengaruh Account Representative (AR) terhadap Kepatuhan Wajib Pajak Orang Pribadi. Penelitian ini mengukur bagaimana pengaruh kualitas pelayanan AR dalam meningkatkan kepatuhan WP Orang Pribadi pada KPP Pratama Sidoarjo Utara. Hasil penelitian menunjukkan bahwa kualitas pelayanan AR berpengaruh signifikan terhadap tingkat kepatuhan WP Orang Pribadi.

- $\quad$ Amilin dan Nina Anisah (2008) meneliti tentang: Pengaruh Persepsi Peran Account Representative terhadap Tingkat Kepatuhan Wajib Pajak. Penelitian ini berusaha mengukur bagaimana peranan 
AR dalam meningkatkan kepatuhan WP pada KPP Pratama Jakarta Pasar Dua. Hasil penelitian menunjukkan bahwa kegiatan pelayanan yang diberikan oleh AR mampu mempengaruhi tingkat kepatuhan WP.

- $\quad$ Arahman Muis (2012) meneliti tentang Pengaruh Pengetahuan Perpajakan, Sanksi Perpajakan, Kesadaran Wajib Pajak dan persepsi Wajib Pajak mengenai Petugas Pajak Terhadap Kepatuhan Pelaporan Wajib Pajak Orang Pribadi pada Kantor Pelayanan Pajak Pratama Surabaya Wonocolo. Penelitian ini bertujuan untuk membuktikan dan menguji secara empiris pengaruh pengetahuan perpajakan, sanksi perpajakan, kesadaran wajib pajak, dan persepsi wajib pajak mengenai petugas pajak terhadap kepatuhan pelaporan wajib pajak orang pribadi pada KPP Pratama Surabaya Wonocolo. Hasil penelitian menunjukkan variabel Persepsi Wajib Pajak mengenai petugas pajak memberikan kontribusi terhadap Kepatuhan Pelaporan Wajib Pajak Orang pribadi pada KPP Pratama Surabaya Wonocolo, sedangkan variabel Pengetahuan Perpajakan, Sanksi Perpajakan, dan Kesadaran Wajib Pajak, tidak memberi kontribusi terhadap kepatuhan Pelaporan Wajib Pajak Orang Pribadi pada KPP Pratama Surabaya Wonocolo.
Berikut ini adalah model penelitian:

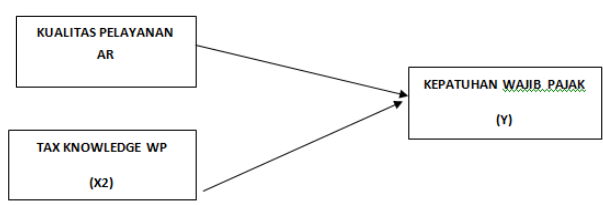

\section{Hipotesis Penelitian}

Hipotesis 1:

Kualitas pelayanan AR berpengaruh signifikan terhadap tingkat kepatuhan WP di Wilayah KPP Madya Bandung.

Hipotesis 2:

Tax knowledge berpengaruh signifikan terhadap tingkat kepatuhan WP di Wilayah KPP Madya Bandung.

\section{Metode Penelitian}

Populasi yang akan diamati dalam penelitian ini adalah WP Badan yang terdaftar pada KPP Madya Bandung tahun 2016 sebanyak 695 WP Badan. Teknik pengambilan sampel dalam penelitian ini adalah teknik incidental sampling.Teknik incidental sampling adalah teknik penentuan sampel berdasarkan kebetulan yaitu siapa saja yang secara kebetulan bertemu dengan peneliti dapat digunakan sebagai sampel, apabila orang yang kebetulan ditemui cocok sebagai sumber data (Sugiyono2014). Alasan pemilihan teknik pengambilan sampel ini adalah untuk mempermudah proses pengambilan sampel. Penentuan jumlah sampel penelitian dalam Sekaran (2006) yang menyatakan bahwa jumlah sampel yang memadai untuk penelitian adalah berkisar antara 30 hingga 500. Dalam penelitian ini menggunakan jenis data primer berupa kuesioner yang diberikan kepada responden dan data mengenai gambaran umum instansi yang didapat dari nara sumber. Sumber data primer kuesioner berasal dari para wajib 
pajak badan.Analisis dalam penelitian ini menggunakan persamaan regresi linear berganda.Untuk menguji apakah konstruk (variabel yang tidak dapat diukur secara langsung, tetapi dibentuk melalui dimensidimensi atau indikator-indikator yang diamati) yang telah dirumuskan reliabel dan valid, maka perlu dilakukan pengujian realiabilitas dan validitas. Dalam penelitian ini juga dilakukan uji asumsi klasik, determinasi dan uji hipotesis..

Persamaan regresi yang dirumuskan berdasarkan hipotesis yang dikembangkan adalah sebagai berikut:

$$
\mathrm{Y}=\alpha+\beta 1 \mathrm{X} 1+\beta 2 \mathrm{X} 2+\varepsilon
$$

Keterangan:

$\mathrm{Y}=$ Kepatuhan Wajib Pajak

$\alpha=$ Konstanta

$\beta 1=$ Koefisien regresi variabel kualitas pelayanan Account Representative (AR)

$\beta 2=$ Koefisien regresi variabel $\operatorname{tax}$ knowledge

$\mathrm{X} 1=$ Kualitas pelayanan Account

Representative (AR)

$\mathrm{X} 2=$ tax knowledge

$\varepsilon=$ error

\section{Hasil Penelitian dan Pembahasan}

Penelitian dilakukan pada WP Badan yang terdaftar pada KPP Madya Bandung. Teknik pengambilan sampel dalam penelitian ini adalah teknik incidental sampling. Teknik incidental sampling adalah teknik penentuan sampel berdasarkan kebetulan yaitu siapa saja yang secara kebetulan bertemu dengan peneliti dapat digunakan sebagai sampel, apabila orang yang kebetulan ditemui cocok sebagai sumber data (Sugiyono 2014). Jumlah kuesioner yang disebar dalam penelitian ini sebanyak 120 responden .Namun kuesioner yang terkumpul sebanyak 78 responden yang memenuhi kriteria/syarat penelitian.

\section{Pengujian Instrumen Penelitian Pengujian Validitas}

Dalam penelitian ini, uji validitasnya menggunakan metode pearson yang dilakukan dengan membandingkan antara $r$ hitung dengan $r$ tabelnya. Jika $r$ hitung lebih besar dari $r$ tabel dan nilainya positif, maka pernyataan tersebut dapat dikatakan valid. Untuk variabel Kualitas Pelayanan Account Representaitive (AR) terdapat 12 item pertanyaan yang diuji validitasnya. Dari 12 item pertanyaan tentang Kualitas Pelayanan Account Representative hanya pertanyaan no.1 yang dinyatakan tidak valid, dan item pertanyaan yang lainnya dinyatakan valid.

Untuk variabel Tax Knowledge (TK) terdapat 8 item pertanyaan yang diuji validitasnya. Dari 8 item pertanyaan tentang Tax Knowledge (TK) pertanyaan no.1 dan 6 tidak valid. Untuk variabel Kepatuhan Wajib Pajak (K) terdapat 7 item pertanyaan yang diuji validitasnya. Dari 7 item pertanyaan tentang KepatuhanWajib Pajak (K) semua item pertanyaannya dinyatakan valid karena memenuhi kriteria yang ditentukan.

\section{Pengujian Reliabilitas}

Pengukuran reliabilitas dalam penelitian ini dilakukan dengan menggunakan koefisien Cronbach Alpha. Ada suatu nilai ketentuan untuk mengukur reliabilitas dengan uji statistik Cronbach Alpha ( $\square$ ). Suatu konstruk dikatakan reliabel jika memiliki Cronbach Alpha > 0,6. (Nunnally, 1994). Hasil uji reliabilitas variabel X dan Y dalam penelitian ini menunjukan nilai Cronbach Alpha $>0,6$ sehingga data-data yang digunakan dalam penelitian ini adalah reliabel.

\section{Uji Asumsi Klasik}

\section{Uji Normalitas}

Pada penelitian ini, uji normalitas menggunakan plot grafik histogram.Menurut Ghozali (2013) normal tidaknya suatu data dapat dideteksi juga melalui plot grafik histogram. 


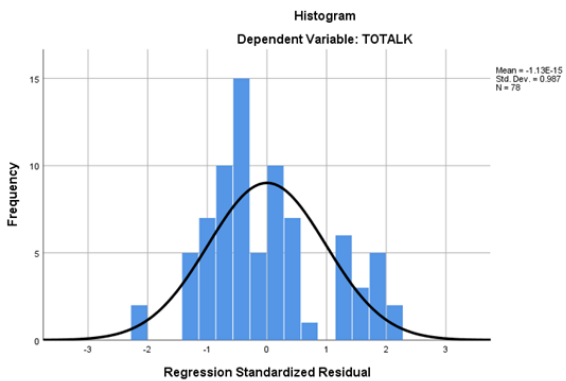

Hasi uji plot grafik histogram menghasilkan kurva yang simetris, sehingga dapatdisimpulkan bahwa data berdistribusi normal.

\section{Uji Multikolinearitas}

Uji Multikolinearitas bertujuan untuk menguji apakah model regresi ditemukan adanya korelasi antar variabel independen.Model regresi yang baik seharusnya tidak terjadi korelasi antar variabel independen.Uji multikolinearitas menggunakan besaran nilai VIF dan nilai Tolerance untuk melihat apakah data terbebas dari multikolinearitas (Ghozali 2006). Tabel dibawah ini menunjukkan bahwa nilai VIF seluruh variabel melebihi 0,1 dan nilai tolerance dibawah 10 . Dengan demikian dapat disimpulkan bahwa data terbebas dari asumsi multikolinearitas.

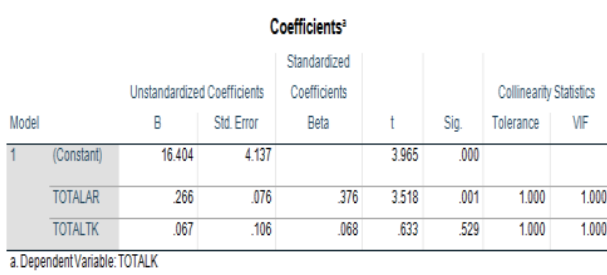

\section{Uji Heterokedastisitas}

Dasar analisis uji heterokedastisitas (Ghozali 2013):

1. Jika ada pola tertentu, sepertititiktitik yang ada membentuk pola tertentu yang teratur, maka mengindikasikan telah terjadi heterokedastisitas.

2. Jika tidak ada pola yang jelas, serta titik-titik menyebar di atas dan di bawah angka 0 pada sumbu $\mathrm{Y}$, maka tidak terjadi heterokedastisitas.

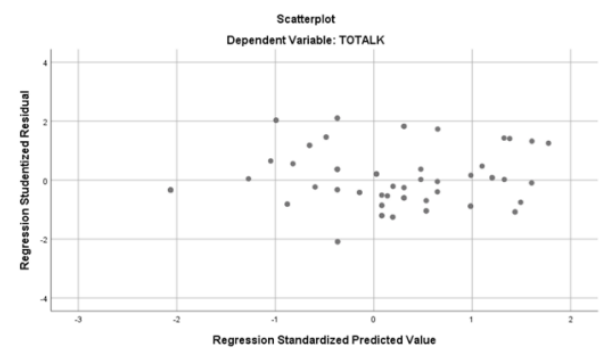

Berdasarkan gambar diatas, gambar tidak membentuk pola tertentu dan titik-titik menyebar di atas dan di bawah angka 0 pada sumbu Y, maka dapat disimpulkan data terbebas dari heterokedastisitas.

\section{Uji Hipotesis}

Dalam pengujian hipotesis, alat uji yang digunakan dalam penelitian ini adalah analisis persamaan regresi linear berganda.

Dari tabel perhitungannya dengan menggunakan SPSS, maka diperoleh output dan persamaan hubungan regresi berganda sebagai berikut:

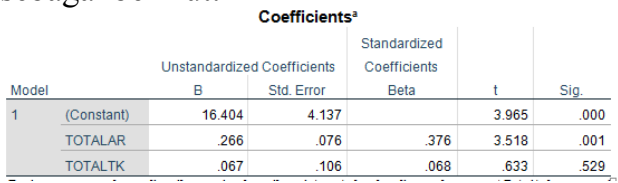

Dari persamaan dapat diuraikan setiap kenaikan 1 (satu) skor kualitas pelayanan AR (x1) dapat meningkatkan 0,418 skor variabel Kepatuhan wajib pajak dan setiap kenaikan 1(satu) skor Tax Knowledge (X2) dapat meningkatkan 0,058 skor variabel Kepatuhan Wajib Pajak.

\section{Uji Regresi Secara Parsial}

Tujuan pengujian ini adalah untuk mengetahui seberapa jauh pengaruh variabel indenpenden secara individual dalam menjelaskan variasi variabel 
dependen. Membandingkan antara nilai $\mathrm{p}$ value dengan tingkat signifikansi 0,05 , maka dapat ditentukan apakah Ho ditolak atau diterima (Ho diterima apabila $\mathrm{p}$ value $>0,05$, Ho ditolak apabila $\mathrm{p}$ value $<0,05$ ) (Ghozali, 2012)

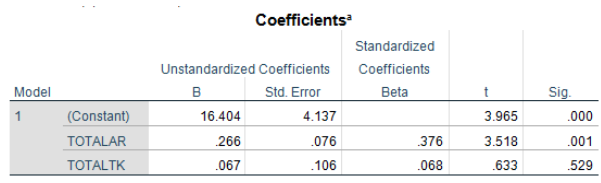

Dari tabel diatas dinyatakan bahwa variabel Kualitas Pelayanan Account Representative (AR) berpengaruh signifikan terhadap Kepatuhan Wajib Pajak, hal ini dapat dilihat dari nilai probabilitas signifikansi $(0,01)<$ 0,05 . Hal ini berarti Ho ditolak. Dengan demikian dinyatakan bahwa variabel kualitas pelayanan AR berpengaruh signifikan terhadap Kepatuhan Wajib Pajak. Dari tabel diatas dinyatakan bahwa variabel Tax Knowledge tidak berpengaruh signifikan terhadap Kepatuhan Wajib Pajak, hal ini dapat dilihat dari nilai probabilitas signifikansi $(0,529)>0,05$. Hal ini berarti Ho tidak dapat ditolak. Dengan demikian dapat dinyatakan bahwa variabel Tax Knowledge berpengaruh signifikan terhadap Kepatuhan Wajib Pajak.

\section{Koefisien Determinasi}

Analisis ini digunakan untuk mengetahui derajat atau kekuatan hubungan antara variabel X1 dan X2 dengan variabel $\mathrm{Y}$ secara bersama-sama. Analisis ini dapat dilihat dari nilai Adjusted RSquarex 100\%

\begin{tabular}{l|c|c|c|c}
\multicolumn{9}{c}{ Model Summary } \\
Model & $\mathrm{R}$ & R Square & $\begin{array}{c}\text { Adjusted R } \\
\text { Square }\end{array}$ & $\begin{array}{c}\text { Std. Error of the } \\
\text { Estimate }\end{array}$ \\
\hline 1 & $.381^{\mathrm{a}}$ & .145 & .122 & .41436 \\
\hline a. Predictors: (Constant), TOTALTK & TOTALAR &
\end{tabular}

Dari data diatas dapat dinyatakan bahwa nilai Adjusted $R$ Square nya sebesar $0,122 \mathrm{x}$ $100 \%=12,2 \%$. Hal ini menyatakan bahwa variabel kualitas pelayanan Account Representative (AR) dan Tax Knowledge secara bersama-sama berpengaruh terhadap
Kepatuhan Wajib Pajak sebesar 12,2\% sedangkan sisanya $87,8 \%$ dipengaruhi oleh faktor-faktor lain yang tidak disertakan dalam variabel penelitian.

\section{Simpulan danSaran}

\section{Simpulan}

Dari hasil penelitian ini yang telah dilakukan mengenai pengaruh Kualitas Pelayanan Account Representative, Tax Knowledge terhadap Kepatuhan Wajib Pajak, maka dapat diambil kesimpulan sebagai berikut:

1. Kualitas Pelayanan Account Representative berpengaruh signifikan terhadap Kepatuhan Wajib Pajak. Hal ini senada dengan penelitian yang dilakukan Amilin dan Anisah (2008) dalam studinya mengenai peranan AR dalam meningkatkan kepatuhan WP pada KPP Pratama Jakarta Pasar Dua, menemukan bahwa kegiatan pelayanan yang diberikan oleh AR mampu mempengaruhi tingkat kepatuhan WP. Dalam konstruk yang berbeda, Alfiansyah (2012) juga menemukan bahwa kualitas pelayanan AR berpengaruh signifikan terhadap tingkat kepatuhan WP orang pribadi pada KPP Pratama Sidoarjo Utara.

2. Tax Knowledge tidak berpengaruh signifikan terhadap Kepatuhan Wajib Pajak. Hal ini berbeda dengan teori yang dikemukakan oleh Abuyamin (2010) menyatakan bahwa salah satu faktor penyebab WP secara pasif tidak membayar pajak (tidak patuh) adalah kurangnya pemahaman terhadap hukum pajak. 


\section{Daftar Pustaka}

Abuyamin, Oyok.2010. Perpajakan Pusat dan Daerah. Bandung: Humaniora.

Alfiansyah,Febri. 2012. Pengaruh Account Representative Terhadap Kepatuhan Wajib PajakOrang Pribadi di KPP Pratama Sidoarjo Utara. Jurnal Akuntansi UNESA.Vol 1, No.1.

Amilin dan Anisah, Nina 2008.Pengaruh Persepsi Peran Account Representative TerhadapTingkat Kepatuhan Wajib Pajak. Jurnal Trikonomika.Vol.7, No.2, 145-152

Burton, Richard dan Ilyas, Wirawan B.2008.Hukum Pajak. Jakarta: Salemba Empat.

Carolina, Verani, Martusa,Riki dan Meythi.2011. Tax Culture: Dasar Pelaksanaan ReformasiPerpajakan Menuju Kepatuhan Sukarela.Proceeding Simposium Nasional Perpajakan III "Road Map Reformasi Perpajakan Indonesia menuju Good Governance"

Ghozali, Imam. 2006. Aplikasi Analisis Multivariate dengan Program SPSS (Edisi Ke 4). Semarang:Badan Penerbit Universitas Diponegoro.

Ghozali, Imam.2011. Structural Equation Modeling Metode Alternatif dengan Partial Least Square PLS. Semarang: Badan Penerbit UNDIP.

Ghozali, Imam. 2012. Aplikasi Analisis Multivariate dengan Program IBM SPSS. Yogyakarta: Universitas Diponegoro

Ghozali, Imam.2013.Aplikasi Analisis Multivariate dengan Program SPSS.Edisi Ketujuh Semarang: Badan Penerbit Universitas Diponegoro.

Heryawan,Ahmad.2012.Kepatuhan Pajak di Jabar 45 persen. Diakses 3 Mei 2013 dari:www.ipabionline.com

Hidayat, Nur.2011. Pengaruh Faktor-faktor Reformasi Perpajakan, Sistem Pengendalian Intern dan
Profesionalisme Pegawai terhadapPeningkatan Penerimaan Pajak. Disertasi. Program Doktor Universitas Padjadjaran.

Hutagaol, John. 2007. Perpajakan: Isu-isu Kontemporer. Yogyakarta: Graha Ilmu.

Kasipillai, J.,Aripin,N., and N.A.2003.The Influence of Education on Tax Avoidance and Tax Evasion. eJournal of Tax Research, Vol.1, No.2, pp.134-146.

Keputusan Menteri Keuangan Republik Indonesia No.98/KMK.01/2006 Tentang Account Representative pada Kantor Pelayanan Pajak yang telah Mengimplementasikan Organisasi Modern.

Kurnia, Siti Rahayu.2009. Perpajakan Indonesia, Konsep dan Aspek Formal. Yogyakarta:Graha Ilmu.

Loo, Ern Chen, Mckerchar M, and Hansford Ann.2009.Understanding The Complisnce Behaviour of Malaysian Individual Taxpayaers Using A Mixed Method Approach. Journal of the Australian Tax Teachers Association, Vol.4 No.1, pp.181-202.

Marti,L.O.2010.Taxpayers' attitudes and tax compliance behavior in Kenya. African Journal of Business \& Management, No.1, pp.112-122.

Monsour, E.,Elias,R. and Cruz, C.A.2006. Accounting Students Likelihood of Compliance withTax Preparation Standards.Journal of Business Strategies, Vol.23, No.2.

Muis, Arahman. (2012). Pengaruh Pengetahuan Perpajakan, Sanksi Perpajakan, Kesadaran Wajib Pajak dan Persepsi Wajib Pajak mengenai Petugas Pajak terhadap Kepatuhan Pelaporan Wajib Pajak Orang Pribadi pada Kantor Pelayanan PajakPratama Surabaya Wonocolo.

Nasution, Darmin.2006.Kode Etik Pegawai Direktorat Jernderal Pajak. DJP. 
Palil,M.R.2005. Taxpayers Knowledge: A Descriptive Evidence on Demographic Factors in Malaysia.Jurnal Akuntansi dan Keuangan, Vol.7, No.1, pp.11-21.

Pandiangan, Liberti.2008. Modernisasi dan Reformasi Pelayanan Perpajakan Berdasarkan Undang-Undang Terbaru. Jakarta: Elex Media Komputindo.

Peraturan Menteri Keuangan Republik Indonesia No.192/PMK.03/2007, Tentang Tata Cara Penetapan Wajib Pajak dengan Kriteriatertentu dalam rangka Pengembalian Pendahuluan Kelebihan Pembayaran Pajak.

Peraturan Menteri Keuangan Republik Indonesia No.79/PMK.01/2015, Tentang Account Representative pada Kantor Pelayanan Pajak.

Roshidi, M.A.,Mustafa,H. dan Asri, M.2007. The Effects of Knowledge on Tax Compliance Behaviours Among Malaysian Taxpayers. Business and Information, Vol.4, No.1.

Siti Kurnia Rahayu.2010. Perpajakan Indonesia: Konsep \& Aspek

Sekaran,U.2006. Metode Penelitian untuk bisnis $1.4^{\text {th }}$ ed.Jakarta: Salemba Empat.

Sugiyono.2014.Metode Penelitian Pendidikan Pendekatan Kuantitatif, Kualitatif,dan R \& D.Bandung: Alfabeta.

Sunardi, Soni Gumilar. 2012. Analisis Kinerja Account Representative Pengaruhnya TerhadapKualitas Pemeriksaan Pajak pada Kantor Pelayanan Pajak Pratama di Wilayah kota Bandung. Universitas Komputer Indonesia

Suratno, F.G.Sri dan Purnama, Nursyabani.2004.Analisis Tingkat Kepuasan Wajib Pajak terhadap Kualitas Layanan Kantor Pelayanan Pajak Yogyakarta Dua.Kajian Bisnis dan Manajemen, Vol.7 No.1, pp.6987.
Tjiptono, Fandy.2005.Service, Quality and Satisfaction. Yogyakarta: Penerbit Andi.

Undang-undang Republik Indonesia Nomor 16 Tahun 2009 Tentang Ketentuan Umum dan Tata Cara Perpajakan.

Widayanti dan Nurlis.2010.Faktor-faktor yang Mempengaruhi Kemauan untuk Membayar Pajak Wajib Pajak Orang Pribadi yang Melakukan Pekerjaan Bebas (Studi Kasus pada KPP Prat ama Gambir Tiga).Simposium Nasional Akuntansi 13.

http://ekstensifikasi423blogspot.com/2015/ 05/account-representative-ar-duludan-kini-html 